\title{
PODSKÓRNA REWOLUCJA: TRZY TEZY O MIASTOTWÓRCZYM POTENCJALE LOGISTYKI
}

\section{Streszczenie}

Artykuł stanowi polemiczną próbę przemyślenia roli sektora logistycznego w najważniejszych transformacjach współczesnej tkanki miejskiej. Choć wiele wskazuje na to, że jest on ważnym warunkiem wyłonienia się miasta postindustrialnego, jak również katalizatorem innych, równie krytycznych transformacji, rewolucja w logistyce pozostaje jednym $\mathrm{z}$ najbardziej zmarginalizowanych wydarzeń na gruncie krytycznych badań miejskich. Można za to winić między innymi dominujący namysł nad urbanizacją, który skupiając się na kwestiach aglomeracji i procesach typowych dla ośrodków zachodnich, lekceważy bardziej peryferyjne procesy urbanizacyjne, w tym planetarne upowszechnianie infrastruktury cyrkulacji, która jest niezbywalnym warunkiem materializacji tego, co Henri Lefebvre [2003] nazywał społeczeństwem miejskim. W kontrze do takiego podejścia sieci logistyczne zostaną tu potraktowane jako jedne z najważniejszych wzorców produkcji przestrzeni, które przyczyniają się do upowszechniania miejskości na terenach niezurbanizowanych i dostarczają uzasadnienia dla nowych, asamblażowych ontologii tego, co miejskie.

Slowa kluczowe: logistyka, miasto logistyczne, rozszerzona urbanizacja, infrastruktura, cyrkulacja, miejskość, asamblaż

* Dr, Wydział Nauk Społecznych, Instytut Kulturoznawstwa, Zakład Kulturowych Studiów Miejskich; e-mail: pjusko@amu.edu.pl 


\section{WPROWADZENIE}

Ostatnie pięćdziesiąt lat $\mathrm{w}$ historii urbanizacji przebiega $\mathrm{w}$ iście rewolucyjnym tempie. Za symbol tych przemian uznaje się początek XXI w., kiedy to globalnie ujmowana miejska populacja przeważyła wreszcie nad mieszkańcami wsi. Jak wiadomo, fakt ten wiąże się zwykle z narodzinami megamiast (takich jak Dhaka czy Lagos), a zatem „miejskim przesileniem” Trzeciego Świata [Davis 2009: 11]. Dla wielu badaczy jest to potwierdzenie tego, co w intuicyjny sposób zapowiadał w latach 60. XX w. Henri Lefebvre [2003]. Idzie tu o wzrost znaczenia i planetarny charakter urbanizacji prowadzącej do zaistnienia miejskiego społeczeństwa i, w efekcie, wielowymiarowej transformacji życia gospodarczego, politycznego i społecznego. W świetle tej wizji miejska rewolucja polegałaby na gwałtownym przyroście rozrzuconych po całym globie mieszkańców miast, jak również globalizacji typowo miejskich praktyk i stylów życia. Wiązałaby się również z procesami reurbanizacji umożliwiającymi odrodzenie ośrodków zachodnich [Majer 2014], na czele z szybko adaptującymi się do wyzwań postfordyzmu miastami informacyjnymi czy inteligentnymi. Zwłaszcza jeśli wziąć pod uwagę poprzedzający taką odnowę kryzys miejski z drugiej połowy XX w.

Choć polskie dyskusje nad kwestią miejską przebiegają w obliczu innych trajektorii rozwojowych i wyzwań demograficznych, podobne myślenie o procesach miastotwórczych udziela się także rodzimym badaczom. Można w ten sposób odczytywać na przykład wpływowe teksty Pawła Kubickiego i Andrzeja Ledera, które marginalizując (Kubicki) czy nawet zupełnie ignorując (Leder) głos Lefebvre'a, przykładają ten sam pryzmat miejskiej rewolucji do ogólnych zmian, którym podlegają w ostatnich dekadach Polki i Polacy. Losy tych ostatnich wpisywane są w dominująca w studiach miejskich narrację o aglomeracyjnej, kondensującej mocy miejskości, która kreuje nie tylko nowe formy tego, co miejskie (praktyki kulturowe, działania polityczne, typy przestrzeni itp.), ale i związane z nimi podmiotowości. Na znaczeniu zyskuje tu zwłaszcza dziejowa rola polskiego mieszczaństwa, które w następstwie „prześnionej rewolucji” społecznej lat 1939-1956 [Leder 2014] i spóźnionego „wynajdywania miejskości” [Kubicki 2016] przynosi wreszcie nadzieję na modernizacyjne przyspieszenie postsocjalistycznego (czyt. zacofanego) społeczeństwa.

Jednym z głównych zadań prezentowanego artykułu jest pokazanie, że namysł nad tak rozumianą urbanizacją potwierdza wprawdzie szereg założeń Lefebvre'a na temat społeczeństwa miejskiego, pozostaje jednak stosunkowo niewrażliwy na postulowany przez niego zwrot w badaniach miejskich. Myślę tu o lekceważeniu znanej propozycji, by w miejsce badań nad sztywnymi jed- 
nostkami terytorialnymi (np. miastem) skierować narzędzia badawcze w stronę trudniej uchwytnych procesów i relacji, które umożliwiają planetarną proliferację tego, co miejskie. W kolejnych częściach tego artykułu będę podkreślał, że nie byłoby to możliwe bez prawdziwie ,przeoczonej” rewolucji zapoczątkowanej w latach 60. XX w. za sprawą szeregu innowacji w obszarze transportu i dystrybucji towarów. Mowa tu o rewolucji w logistyce, która doprowadziła nie tylko do materialnego upowszechniania miejskości na obszarach nieobjętych tradycyjnymi procesami aglomeracji, ale również strukturalnego przeobrażenia na gruncie postindustrialnej formy miejskiej.

Wspomniane przeoczenie nie jest jedynie udziałem badań miejskich, ale wszystkich bodaj nauk społecznych (wyłączając ekonomię). Jeszcze w 2007 r., pisząc o współczesnym systemie-mobilności, John Urry [2007], a zatem pionier socjologicznych badań nad ruchem i przepływami, w zasadzie pomijał problem logistyki, niejako oddając $\mathrm{w}$ tej kwestii pole ekonomistom i specjalistom od zarządzania. Podobnie rzecz ma się z teoretykami sieci (Manuel Castells), globalizacji (Zygmunt Bauman, Arjun Appadurai) czy transnarodowych połączeń (Ulf Hannerz), którzy trzymając się w swoich rozważaniach z dala od kwestii infrastrukturalnego wsparcia i materialnych połączeń pomiędzy państwami, miastami i regionami, utwierdzają marginalizowanie logistyki na gruncie badań społecznych. Zmiany takiego stanu rzeczy nie ułatwia skryta natura sektora pełniącego rolę „technologicznej nieświadomości” współczesnych społeczeństw [Thrift 2004] czy rzeczywistej niewidzialnej ręki rynku [Juskowiak 2017], co sprawia, że unaoczniamy sobie jego działanie dopiero w chwili niewydolności lub zatrzymania jego machinerii. Nie bez znaczenia są tutaj również dominujące trendy w zakresie organizacji coraz bardziej ,podziemnej” usieciowionej infrastruktury [Gandy 2014a: 2] oraz procesy offshoringu [Urry, 2013], które ekspediują kluczowe centra produkcji i dystrybucji do krajów niezachodnich (np. ZEA, Chin, Indii), a zatem poza geograficzny horyzont wielu badaczy z półkuli północnej.

Zwrócenie uwagi na takie problemy pozwala mi mówić o podskórnej rewolucji, która być może w nieodwracalny sposób przeobraża fizyczną tkankę miast na całym świecie. Sektor logistyczny zostanie tu potraktowany zatem nie tyle jako spiritus movens szerszych transformacji kapitalizmu, ale przede wszystkim poważne wyzwanie dla przyjmowanych w studiach miejskich założeń ontologicznych i epistemologicznych w kwestii miasta, miejskości i urbanizacji. Tłumaczy to teoretyczny charakter artykułu, który można traktować jako próbę rozciagnięcia postulatu Lefebvre'a także na badania nad materialną infrastrukturą społeczeństwa miejskiego, jak również poszukiwania typowo przestrzennych skutków 
dla zjawiska logistyfikacji, czyli ogólnego procesu przyspieszania, wygładzania i łączenia kluczowych elementów współczesnej gospodarki [LeCavalier 2016: 6].

Prezentowany tekst składa się z trzech części rozwijających przedstawione poniżej tezy. W pierwszej $\mathrm{z}$ nich podkreślam rolę logistyki $\mathrm{w}$ deindustrializacji i reurbanizacji dawnych ośrodków przemysłowych, widząc w niej ważne podłoże dla narodzin miasta postindustrialnego. Druga teza przenosi akcent na międzymiejskie i ponadpaństwowe sieci logistyczne jako wehikuły planetarnej urbanizacji oraz eksplozji tradycyjnych porządków przestrzennych (w tym samego miasta). Trzecia, opisując stosunkowo nowy twór przestrzenny, czyli miasto logistyczne, przekonuje, że można w nim widzieć stale zyskującą na znaczeniu formę miejską $\mathrm{i}$ istotne wyzwanie dla popularnych koncepcji miasta globalnego.

\section{TEZA 1: LOGISTYKA STANOWI PODSTAWOWY, CHOĆ WCIAŻ̇ NIEDOSTATECZNIE ZBADANY WARUNEK MOŻLIWOŚCI MIASTA POSTINDUSTRIALNEGO}

To, kiedy logistyka wikła się w procesy miastotwórcze, pozostaje kwestią sporna. Najdalej w przeszłość sięgające genealogie wskazują na militarne korzenie rzymskiego planu siatkowego upowszechnianego w podbitych przez Rzymian prowincjach cesarstwa. Uzasadnia to podporządkowanie tak planowanych osad swobodnej cyrkulacji ludzi i dóbr, jak również dbałość o jakość dróg łączących zależne od Rzymu miasta ze stolicą starożytnego państwa. Późniejsza kariera charakterystycznej kratownicy mogłaby zatem wskazywać na istotowo logistyczne korzenie europejskiej urbanistyki, trzeba jednak pamiętać, że logistyka wojskowa w nowoczesnym sensie wyłania się dopiero między połową XVI a początkiem XVIII w. [Neilson 2012: 322], by zyskać dojrzałą postać w okresie wojen napoleońskich. Równie dużo niepewności towarzyszy innemu podręcznikowemu przykładowi, czyli haussmannizacji Paryża (1853-1870). Bo jeśli nawet przebudowa francuskiej ,stolicy nowoczesności” nie byłaby możliwa bez rozwiniętego systemu transportu i komunikacji, to o pełnoprawnej logistyce nadal myśli się wtedy tylko w kontekście sztuki wojennej. Przypadek Paryża II Cesarstwa jest jednak znaczący, bowiem za sprawą posunięć Georges'a Haussmanna zaczyna on nabierać rysów typowych dla znacznie późniejszych transformacji. Wskazuje na to David Harvey [2006], podkreślając nie tylko główny imperatyw Haussmannowskiej restrukturyzacji, czyli zwiększenie skali i tempa cyrkulacji (ludzi, towarów, wojska, pieniędzy, powietrza itd.), ale też szereg zjawisk, które określają wyjątkowość Paryża na długo przed tym, zanim ktokolwiek napisze o społeczeństwie poprzemysłowym. Chodzi tu głównie o deindustrializację 
i deruralizację paryskiego śródmieścia, które zmuszą miasto do rozwinięcia ponadlokalnego systemu dostaw, ale i procesy (proto)gentryfikacji, spekulacji na rynku nieruchomości czy spektakularnego utowarowienia miejskiej kultury, które tak mocno kojarzymy dziś z miastem drugiej połowy XX w.

Niezależnie od tego, czy uznamy haussmannizację za początek miastotwórczej działalności logistyki, sektor ten zdradza taki potencjał, tkwiąc jeszcze ściśle w przemysłowej formie miejskiej i fordowskiej mutacji kapitalizmu. Nowe rodzi się w tym wypadku w skorupie starego, dobrze korespondując z materialistycznym spojrzeniem na historię i geografię [por. Harvey 2006: 1-17]. Chodzi tu zwłaszcza o zmiany, jakim podlega logistyka wojskowa w czasie dwóch wojen światowych, co prowadzi do: umocnienia jej pozycji względem dominujących nad nią wcześniej strategii i taktyki; upowszechnienia praktyk przewidywania, kalkulacji i miary; oraz testowania jej przyszłych innowacji, np. technik just-in-time i formy kontenerowej [Cowen 2014: 30-31]. Równie ważna będzie zmiana myślenia o ogólnym charakterze cyrkulacji, zapowiadana sto lat wcześniej przez Marksa [1977, 1986; por. Juskowiak 2017] w związku z możliwościami otwieranymi dla kapitału za sprawą rewolucjonizowania środków komunikacji. Znaczenie ma tu głównie nowe podejście do transportu i organizacji przestrzeni, które doprowadzi cały sektor (w latach 60.) do rezygnacji z obowiązującej do tej pory „doktryny” minimalizacji kosztów na etapie postprodukcji (czyli ruchu skończonych towarów) na rzecz podejścia skupionego na maksymalizacji zysków za sprawą racjonalizacji dystrybucji, umożliwionego przez systemowe spojrzenie na cały sektor [Cowen 2014: 33-35]. Logistyka będzie odtąd traktowana jako wewnętrznie zróżnicowana dziedzina, która łącząc takie funkcje, jak przetwarzanie zamówień, magazynowanie, marketing czy transport, staje się przewodnim elementem struktury organizacyjnej większości zaangażowanych w globalny handel firm [Allen 1997: 110].

Jeśli traktować logistykę jako makroinnowację, która zmienia świat z podobną skutecznością jak silnik parowy czy Internet [Lyster 2016: 9], to w kontenerze trzeba widzieć najważniejszy wynalazek dla globalizacji handlu [Cowen 2014: 41] i związanej z nią organizacji przestrzeni. Konteneryzacja ma wielu ojców i złożone korzenie, większość opracowań wskazuje jednak na kluczową rolę Malcoma McLeana [Levinson 2016; Cowen 2014], przedsiębiorcy, który jako pierwszy dostrzegł w skutecznej organizacji mobilności centralny punkt globalnej gospodarki [Parker 2013: 370]. Skromne początki tego procesu - czyli pierwszy udany transport kontenerów drogą morską z Newark, NJ do Houston w kwietniu 1956 r. - jedynie zaostrzają apetyty rewolucjonistów, którzy w kilka dekad doprowadzą do narodzin globalnego łańcucha dostaw. Jak pisze Cowen 
[2014: 41]: „konteneryzacja radykalnie zmniejszyła czas potrzebny do załadunku i rozładunku statków, zredukowała koszty pracy w portach i umożliwiła niesłychane oszczędności wśród wytwórców, którzy mogli ograniczyć swoje zapasy do niezbędnego minimum". Była też bodaj najdoskonalszym remedium na recesję dławiącą kapitalizm w latach 70., dając szansę na niemal bezbolesne (z czym nie zgodziliby się robotnicy) przeniesienie przemysłowych fabryk do słabiej uzwiązkowionych i niżej szacujących koszty pracy państw latynoamerykańskich czy azjatyckich. Zatem to w logistyce widzieć należy uzasadnienie dla pozornie paradoksalnej prawidłowości, zgodnie z którą przejście do postindustrialnego modelu gospodarki nie tylko nie zmniejsza globalnej populacji robotników przemysłowych, ale prowadzi do rekordowego wzrostu ich liczby w skali całego kapitalistycznego świata. Deindustrializacja takich państw jak USA czy Wielka Brytania ma bowiem sens tylko w związku z wzmożoną industrializacją Chin, Turcji czy Pakistanu. Jak zauważa w tym kontekście Boris Vormann [2015: 359], niejako wbrew intuicji „postindustrialne społeczeństwo konsumpcyjne opiera się na zglobalizowanym modelu produkcji wytwórczej".

Choć tego rodzaju relacyjne spojrzenie na zmiany gospodarcze jest silnie obecne w pracach na temat neoliberalizmu [Harvey 2012], offshoringu [Urry 2013] czy usieciowienia gospodarki [Castells 2007], podobne nastawienie rzadko towarzyszy dominującemu myśleniu o mieście postindustrialnym. Często pisze się o nim z perspektywy wewnętrznej (skala pojedynczego ośrodka) z wyraźnym odwołaniem do obcych fordyzmowi niematerialnych: usług, informacji i wiedzy czy praktyk kulturowych. Ta dematerializacja namysłu nad kwestią miejską rodzi liczne problemy zapowiadane już przez Castellsa [1982] w jego krytyce „kultury miejskiej” jako ideologicznej zasłony dla strukturalnych procesów targających miastem przemysłowym. Mając na uwadze transformacyjny potencjał logistyki, należy zauważyć, że główną wadą typowego spojrzenia na miasto postindustrialne jest podobne abstrahowanie od wpływu materialnych sieci na fundamentalne zmiany w obrębie formy miejskiej. Zarzut ten można zresztą postawić również Castellsowi [2007], który skupiając się na narodzinach społeczeństwa sieci, marginalizuje rolę odgrywaną w tym wypadku przez globalny łańcuch dostaw. Także słynny podział na typową dla tego społeczeństwa (oraz miasta postindustrialnego) przestrzeń przepływów i przestrzeń miejsc dokonywany jest w oderwaniu od pogłębionego namysłu nad tym, jakie rozwiązania infrastrukturalne pozwalają im się ze sobą łączyć [Mezzadra, Neilson 2013: 210]. Pełne zrozumienie pierwszej tezy tego artykułu polega zatem nie tylko na przyjęciu perspektywy materialistycznej, do czego przyznaje się i Castells [2007: 412], ale również „infrastrukturalnej krytyki zmiany miejskiej” [Vormann 2015: 356,363], 
która daje nam szansę na bardziej relacyjne, dialektyczne i rozwijane w obliczu różnych skal geograficznych spojrzenie na procesy miejskiej restrukturyzacji. W przypadku badań Castellsa dotyczyłoby ono na przykład transkontynentalnych sieci produkcji-dystrybucji, bez których nie mogłyby się materializować pomysły inżynierów Apple’a czy Samsunga.

Rozumiana w ten sposób logistyka powinna być zatem traktowana jako jeden z głównych warunków możliwości wyłonienia się miast postindustrialnych, nie wykluczając pionierskich w tym względzie Londynu czy Nowego Jorku. Dzieje się tak przynajmniej z dwóch powodów. Pierwszy wiąże się z dawaną przez łańcuch dostaw możliwością niemal pełnego uniezależnienia od wewnętrznego sektora produkcji, co okazuje się szczególnie atrakcyjne z uwagi na: „konieczność rozbudowy najprężniejszych przedsiębiorstw, co uniemożliwiała zwarta zabudowa miast [zachodnich]; wprowadzenie bardziej rygorystycznych ustaw o ochronie środowiska; rosnące ceny gruntów na terenach zurbanizowanych; zbyt małe nakłady na modernizację fabryk; polityczną siłę i poziom zarobków uzwiązkowionej siły roboczej" [Juskowiak 2015: 58-59].

Oparcie na „niezawodnym” łańcuchu dostaw (o co dbają skomplikowane systemy bezpieczeństwa, obiegu danych i wygładzania przestrzeni powołane do walki z sektorową przygodnością [Rossiter 2016]) daje też szansę zmierzenia się z wyzwaniem demograficznym. Stały przypływ mieszkańców, zwłaszcza do miast globalnych i megamiast, to jeden z powodów rosnącego znaczenia sieci infrastrukturalnych transferujących do coraz ludniejszych ośrodków podstawowe media i dobra, co czyni z nich zresztą miejskie miękkie podbrzusza narażone na kataklizmy ekologiczne, awarie czy świadome próby zatrzymania.

Drugi powód polega na zwolnieniu pod inwestycje ogromnej przestrzeni, w której mogą pojawić się teraz tak typowe dla omawianej formy miejskiej przykłady refunkcjonalizacji (reurbanizacji) dawnej substancji przemysłowej. Szczególną estymą władz miejskich cieszą się w tym kontekście instytucje kulturalne (vide Tabakalera w San Sebastian, Technopolis w Atenach), choć w ostatnich latach nie brakuje też udanych przykładów poprzemysłowych centrów handlowych (Stary Browar w Poznaniu, Manufaktura w Łodzi) czy ogólniejszych procesów reindustrializacji, wprowadzających do śródmieścia blask innowacji kojarzonych na przykład z przemysłami kreatywnymi.

Jeśli w wielu przypadkach rola logistyki może się wydawać pośrednia, polegając $\mathrm{z}$ grubsza na wyprowadzaniu przemysłu poza centralne fragmenty miasta, to taka wizja jest nie do utrzymania, gdy idzie o restrukturyzację miejskich węzłów dystrybucji. Transformacyjny impet konteneryzacji uwypukla się bowiem najmocniej w przypadku przestrzeni portowych, wymuszając na nich 
adaptację do nowych warunków globalnego handlu. Wiele z nich temu wyzwaniu zwyczajnie nie sprostało, by wskazać długoletnie problemy londyńskiego Docklands (przezwyciężone ostatecznie dzięki równoległej do deindustrializacji centralizacji kapitału finansowego). Inne odniosły w tej materii niemały sukces, pozostając w grze mimo ogromnych kosztów przystosowania do obsługi kontenerowców. Szczególnie ciekawe są przykłady takich miast, którym udało się nie tylko zachować dawną funkcję przy uzyskaniu zwiększonej przepustowości swoich portów, ale również poprzez przesunięcie miejsc pełniących tę funkcję $\mathrm{z}$ dala od centralnych fragmentów nadbrzeża umożliwić restrukturyzację tego, co portem być już nie musi (vide Hamburg i HafenCity). Na uwagę zasługuje tu na przykład Liverpool, który przeszedł swoją rewolucję w ciągu zaledwie dwudziestu lat. Transformacji poddano przy tym jedynie dwa skrajnie usytuowane doki (Seaforth i Garston), które dawały możliwość znacznej ingerencji w istniejącą zabudowę. Oba uzyskują zresztą większą wydajność niż wszystkie doki razem wzięte $\mathrm{w}$ okresie sprzed konteneryzacji, co okupiono utrata pracy około 10 tys. dokerów. Inne „ofiary” procesu to wciąż ogromne połacie niszczejącej infrastruktury. Centralnie usytuowane obszary, zwłaszcza zrewitalizowane z wielką pompa Albert Dock i przystań Piers Head, opowiadają jednak bardziej optymistyczną historię - o mieście, które nie wstydząc się swojej przemysłowej przeszłości, dołącza do innych metropolii rywalizujących na jakość oferty kulturalnej i turystycznej. Mowa tu jednak o dwóch stronach tego samego medalu postindustrialnej zmiany miejskiej. Ich uwzględnienie pozwala wydobyć na jaw jedno z podstawowych osiagnięć miastotwórczej co do zasady logistyki. Nie tylko zmieniającej sposoby, w jakie konsumujemy dobra, ale odpowiedzialnej również za twórczo-destrukcyjne transformacje przestrzeni [Harvey 2015: 155].

\section{TEZA 2: SIECI LOGISTYCZNE JAKO MATERIALNE PRZEDLUŻENIA I FORMY UPOWSZECHNIENIA MIEJSKOŚCI ODPOWIADAJĄ ZA DEKONSTRUKCJĘ/EKSPLOZJE TRADYCYJNYCH PORZĄDKÓW PRZESTRZENNYCH}

Teza, zgodnie z którą bez rozbudowanego systemu logistyki nie byłoby miasta postindustrialnego, jest często zapominaną prawdą, nie da się jednak o niej myśleć jako o wyzwaniu dla post-Lefebvre'owskich badań miejskich. Nadal zajmuje nas tu bowiem tradycyjna forma miejska, która zgodnie z La Révolution urbaine nie tylko nie występuje już w „naturze”, ale jest też stosunkowo anachronicznym obiektem naukowego namysłu. Inaczej rzecz ma się z drugą tezą artykułu, która przekonuje, że logistyka, w dosłowny sposób materializując intuicje francuskiego 
badacza, zmusza nas do przemyślenia głównych założeń ontologicznych i epistemologicznych na temat miasta, miejskości i urbanizacji. Choć perspektywa ta bywa krytykowana za brak precyzji i oderwanie od strukturalnych czynników napędzających miejskie procesy, trudno o lepszy punkt wyjścia do diagnozowania zmian, którym podlega dziś urbanizacja. Na pierwszy plan wybija się tu dostrzeżona przez niego dialektyka implozji-eksplozji [Lefebvre 2003: 14], która pozwala widzieć procesy miastotwórcze zarówno w perspektywie akumulacji tego, co miejskie w różnej wielkości ośrodkach, jak i w odniesieniu do działań rozpraszających typowo miejskie własności i praktyki na terenach niezurbanizowanych.

Jak odnotowałem we wprowadzeniu, pomimo rosnacego zainteresowania takimi zagadnieniami, jak rozlewanie się i usieciowienie miast czy nowe fale suburbanizacji w typowych spojrzeniach na kwestię miejską wciąż dominuje perspektywa sprowadzająca urbanizację do zjawisk koncentracyjnych [Brenner, Schmid 2015: 154]. Idzie tu nawet nie tyle o lekceważenie takich jej przykładów, które dezintegrują i rozpraszają miejskie terytorium, ile o przyglądanie się owym procesom wyłącznie od strony miasta, z pominięciem skutków, jakie niesie to dla obszarów niezurbanizowanych (np. wsi). Stanowisko takie bywa określane metodologicznym miastocentryzmem [Angelo, Wachsmuth 2015] i łączy się z szeregiem innych aktów hierarchizacji (np. uprzywilejowaniem metropolii i miast globalnych itd.), którym tak często ulegają zachodni badacze miasta. Za przykład służyć tu mogą nawet książki Andy’ego Merrifielda [2016], w których miejskość sprowadza się głównie do zjawiska kondensacji (miasta i wsi, Północy i Południa, ludzi i kapitału), przypominając momentami naiwne głosy o uwspólniającej mocy globalnej wioski. Wizjonerstwo Lefebvre'a sprowadza się tymczasem do przekonania, że miasto jest tylko jednym z efektów urbanizacji, do tego wypadkową szerszych i usytuowanych poza nim procesów społecznych, ekonomicznych i politycznych [Gandy 2014b: 86].

Jedną z ciekawszych propozycji z obszaru studiów miejskich jest w tym kontekście postulowana przez Neila Brennera i Christiana Schmida [2015: 162] próba ich epistemologicznego otwarcia na problem rozszerzonej urbanizacji, którą należy rozumieć jako „fundamentalne warunki możliwości dla produkcji historycznie i geograficznie specyficznych form miejskości” oraz badać wespół z dialektycznie z nią powiązanymi urbanizacją skoncentrowaną (a zatem sojuszniczką aglomeracji) i urbanizacją różnicującą (sprzyjającą aktom twórczej destrukcji). Choć każdy z tych wymiarów sporo zawdzięcza infrastrukturze logistycznej, to jej obecność przejawia się szczególnie mocno w ramach urbanizacji rozszerzonej, odpowiedzialnej za podpięcie codziennych elementów życia miejskiego do sieci wspierających je „miejsc, terytoriów i krajobrazów” 
często oddalonych od głównych skupisk populacji [Brenner, Schmid 2015: 167]. Kwestia tego rodzaju wsparcia jest bardzo ważna, zwłaszcza gdy zgodzić się z tymi ujęciami logistyki, które widzą w niej rodzaj witalnego systemu [Cowen 2014: 216] odpowiedzialnego za stabilne funkcjonowanie i reprodukcję wspomaganych przezeń organizmów. Druga cecha tak przedstawionego procesu to „stała konstrukcja i reorganizacja stosunkowo niezmiennych i nieruchomych infrastruktur (szczególnie dla transportu i komunikacji)" służąca nie tylko wsparciu wspomnianego życia, ale również „nierównemu zagęszczaniu i rozciaganiu tkanki miejskiej" na kolejne skrawki planety [Brenner, Schmid 2015: 167]. Można by tu mówić o dosłownej materializacji miejskości, która zwykle bywa utożsamiana raczej z niematerialnymi sposobami życia czy wartościami kulturowymi. Wreszcie, trzecia właściwość urbanizacji rozszerzonej wiąże się z powszechnym dziś zjawiskiem grodzeń ziemi i zasobów naturalnych, co pozwala ją traktować jako szczególną instancję szerszego procesu neoliberalnych wywłaszczeń, szczególnie chętnie analizowanych przez miejskich marksistów [Harvey 2015; Merrifield 2016].

Widząc w infrastrukturze logistycznej uprzywilejowany przez kapitalizm wyraz rozszerzonej urbanizacji, przejdę teraz do skrótowego opisu składających się na nią tworów przestrzennych. Większość z nich wpisuje się w drugi, najistotniejszy po konteneryzacji, wynalazek logistycznej rewolucji, czyli ustanowienie globalnego łańcucha dostaw. Pierwsza urbanistyczna eksplozja, z którą można kojarzyć transformacyjny impet logistyki, polega zatem na dezartykulacji dotychczasowo zwartej przestrzeni produkcyjnej do postaci „części składowych, które da się rozciągać i na nowo łączyć w bardziej złożone konfiguracje" [Cowen 2014: 103]. Tym, czego nie da się w tym kontekście przecenić, jest oczywiście rewolucja na gruncie środków transportu, które stwarzają możliwość wytwarzania towarów nie tyle w pojedynczych budynkach czy dzielnicach, ale na przestrzeni całej logistycznej sieci (co zresztą mocno nadweręża podział na sfery produkcji i dystrybucji). Zdaniem Deborah Cowen proces ten odpowiada za narodziny skrajnie pokawałkowanej globalnej fabryki logistycznej, która nawet na niższych poziomach swojej złożonej konstrukcji (konkretne szlaki i korytarze handlowe, specjalne strefy ekonomiczne, miasta logistyczne) przyczynia się do głębokiego przeobrażenia dotychczasowych układów przestrzennych. Często dosłownie je niszczy lub przynajmniej neutralizuje z myślą o nowych wymogach cyrkulującego kapitału, co widać na przykład w ramach wyłaniającego się za sprawą logistycznej dekoncentracji i suburbanizacji policentrycznego miasta-regionu [Hesse 2008: 24-26]. 
Tacy autorzy jak Brett Neilson [2012] czy Ned Rossiter [2016] podkreślają wobec tego wybitnie polityczny charakter logistyki, która, będąc jednym z warunków możliwości neoliberalizmu, okazuje się ważnym czynnikiem w ustanawianiu nowej kartografii polityczności [Cowen 2014: 62]. Geoekonomiczna propozycja, za którą stoją systemy logistyczne, uderza przede wszystkim w sztywne narodowe granice i stare regulacje prawne, tworząc w ich miejsce dużo bardziej heterogeniczne - bo skupione na segmentacji, hierarchizacji i koordynacji ruchu [Mezzadra, Neilson 2013: 209] - transnarodowe sieci materialnych połączeń pomiędzy różnymi częściami łańcucha dostaw. Wiele logistycznych rozwiązań funkcjonuje na zasadzie przestrzennych enklaw [Graham, Martin 2001:357-372], które korzystając z tunelowego efektu sieci, odłączają się od własnego otoczenia geograficznego na rzecz zanurzenia w globalnej przestrzeni przepływów. Świetnym przykładem takiego paradoksalnego usytuowania są tzw. zony, czyli ponadi pozapaństwowe strefy cyrkulacji (wolnego handlu, przetwórstwa wywozowego itp.) powołane do usprawniania i przyspieszania operacji kapitału [Easterling 2014: 25-69]. Choć można by o nich mówić jako o przestrzeniach wyjątku, sednem logistycznego projektu jest nowa geograficzna norma opierająca się na tworzeniu jednolitego porządku globalnego, który kompresując, synchronizując i uabstrakcyjniając możliwie całą dostępną przestrzeń [Juskowiak, 2017], znosi tak kluczowe, geopolityczne podziały jak Schmittowskie przeciwstawienie lądu i morza (z uwagi na to, że $90 \%$ towarów dociera dziś do konsumentów dzięki kontenerowcom) [por. Neilson, Rossiter 2011: 53] czy zimnowojenne rozróżnienie Pierwszego, Drugiego i Trzeciego Świata.

Wiele wysiłku wkłada się w tym kontekście w stworzenie monumentalnej, ponadpaństwowej infrastruktury transportowej, która ma funkcjonować na zasadzie zdeterytorializowanej, gładkiej przestrzeni opisywanej we wpływowych tekstach Gilles'a Deleuze'a i Felixa Guattariego [2016]. Jako że zasięg takich inwestycji nie pokrywa się po prostu z państwem, a ich finansowaniem i obsługą interesują się równie mocno sektor publiczny i prywatny, fabryczny asamblaż logistyki powstaje w poprzek charakterystycznych dla nich porządków przestrzennych. Wśród wielu projektów składających się na nową ,geografię przejść i korytarzy" [Cowen 2014: 64-67] warto wyróżnić wspierany przez North America's SuperCorridor Coalition plan budowy multimodalnego systemu transportowego przebiegającego przez połowę Ameryki Północnej czy przecinający północno-zachodnie wybrzeże USA, na razie jako sieć autostrad, Canamex Corridor. To, że takie inicjatywy rozpalają również wyobraźnię inwestorów w Afryce i Azji (vide korytarz logistyczny pod patronatem Stowarzyszenia Narodów Azji Połu- 
dniowo-Wschodniej łączący Mjanmę, Chiny, Laos i Wietnam), świadczy o tym, że logistyczne innowacje od dawna nie są udziałem jedynie państw zachodnich. Głośno jest w tym kontekście zwłaszcza o finansowanym przez Chiny „nowym jedwabnym szlaku", który stwarzając infrastrukturalne umocnienia dla ich współpracy z resztą Azji i Europa, a docelowo również z Afryka, potwierdzałby pozycję tego państwa jako pierwszego logistycznego imperium [Cowen 2014: 67]. Ważnym krokiem do spełnienia tego marzenia jest niedawna (2016 r.) prywatyzacja portu w greckim Pireusie, która całkiem dosłownie otwiera europejskie przejście dla chińskiego kapitału, kultury korporacyjnej oraz logistycznego sposobu organizacji przestrzeni i modelu pracy.

Druga kluczowa eksplozja dotyczy już samego miasta. Choć traktowanie go jako sztywnej jednostki terytorialnej czy ograniczonej formy osadniczej można by kwestionować już w czasach starożytnych, dopiero dzisiaj do głosu dochodzi przekonanie o jego inherentnie pokawałkowanej i płynnej, bo zdanej na infrastrukturalnie mediowane przepływy, konstytucji [zob. Graham i Marvin 2001: 8]. Fakt ten akcentują zwłaszcza nowe ontologie tego, co miejskie, które przedstawiają miasto w kategoriach pozbawionej sztywnych granic maszyny [Amin, Thrift 2016: 3] nieistniejącej inaczej niż jako wypadkowa działań systemów społeczno-technicznych i część bardziej złożonej geograficznie sieci. Rola logistyki jest w tym wypadku trudna do zlekceważenia, ponieważ jako jeden z głównych tego rodzaju systemów przyczynia się do swoistego poruszenia stabilnego przestrzennie i tożsamościowo miasta. Zmuszając je do wyjścia z dotychczasowej formy (dzięki wzmożonej obecności takiej sieciowej infrastruktury jak pozamiejskie centra dystrybucji czy huby komunikacyjne), przekierowuje je w stronę bardziej asamblażowej konstrukcji, która łączyłaby heterogeniczne elementy o różnej skali i złożoności (miasto, obszary podmiejskie) wykorzystując nakładający się na nie wszystkie łańcuch dostaw [por. Hesse 2010: 76]. Słynny postulat Lefebvre'a da się z tego powodu odnosić już nie tylko do miejskości, ale także stale transformujących się form miasta, które należy ujmować „z perspektywy jego systemów operacyjnych i proceduralnych przepływów" [Lyster 2016: 1] organizujących cyrkulację ludzi, kapitału, pojazdów i informacji.

Wracamy w ten sposób do kwestii rozszerzonej urbanizacji, która nie tylko odpowiada za materialne upowszechnienie miejskości na terenach niezurbanizowanych, ale stawia też pod znakiem zapytania dominujące myślenie o aglomeracji. Odniesienie do asamblażu, zwłaszcza w jego post-deleuzjańskim rozumieniu [McFarlane 2011], jest tu bardzo zasadne, pomaga bowiem uchwycić kwestię miejskiej eksplozji nie tylko w kategoriach stale rozrastających się megastruktur 
[Soja, Kanai 2014], ale w znaczeniu topologicznie formowanych „gęstych pól sił” [Brenner, Schmid 2015: 173] będących efektem spotkania różnych logik ekonomicznych i geograficznych, ,których nie musi nic specjalnego łączyć w samym punkcie przecięcia" [Amin, Thrift 2016: 102]. Takie spojrzenie wyraźnie odbiega od popularnych koncepcji, które źródeł ekonomicznej i kulturowej siły danego miasta lub regionu doszukiwałyby się w zjawiskach klastrowania, koncentracji ludzi czy współwystępowania specyficznych form gospodarki. Z braku miejsca podkreślmy tylko, że główne znaczenie ma tu cechujący różne asamblażowe ontologie nacisk na przygodne procesy składania i rozpraszania heterogenicznych elementów [DeLanda 2006], jak również społeczno-materialny charakter tych relacji. Pozwala to myśleć o mieście i życiu miejskim w związku z takimi sprawczymi zjawiskami, jak przepływy wiedzy, zmiana technologiczna czy procesy naturalne, i poza takimi dychotomiami, jak bliskie-dalekie, wewnętrzne-zewnętrzne, ludzkie-nieludzkie. Co istotne, o kształcie określonego asamblażu decyduje nie tyle współobecność określonych części, ile zachodzące między nimi interakcje, czyniące z interesującego nas bytu miejskiego zawsze niestabilny zwornik dla dynamicznych przepływów, nigdy zaś sztywny układ elementów czy organiczną całość. Nie oznacza to jednak, że nie jest on podporządkowany określonym hierarchiom czy strukturom władzy. Przeciwnie. To jak składany i utrwalany jest $\mathrm{w}$ danej chwili miejski asamblaż, ma sporo wspólnego z istotowo nierówną i niesprawiedliwą dynamiką życia polityczno-gospodarczego w warunkach kapitalizmu [McFarlane 2011: 656]. Uwaga ta szczególnie mocno tyczy się podtrzymującej życie infrastruktury, która, jak w przypadku sieci logistycznych, pozostając $\mathrm{w}$ znacznej mierze $\mathrm{w}$ gestii sektora prywatnego, jest w stanie spełniać swoją funkcję tylko dzięki równoczesnemu ryzykowaniu życiem i zdrowiem osób zaangażowanych w dobrostan torów przestrzennej cyrkulacji towarów (vide warunki pracy w centrach logistycznych i portach kontenerowych).

Ta sama infrastruktura traktowana w kategoriach podskórnej tkanki miejskiej jest zresztą tym elementem układanki, który konkretyzuje bardzo abstrakcyjne w tym miejscu rozważania na temat formy miejskiej. Podkreślają to Ash Amin i Nigel Thrift [2016: 107], widząc w rozwiązaniach oferowanych przez sieciową infrastrukturę warunek możliwości przechodzenia od prostej kwestii osadnictwa, zależnej od lokalizacji i terytorialnych ograniczeń, do miasta funkcjonującego zawsze poza sobą samym dzięki ciaggle rosnącemu zasięgowi zakorzenionych w nim wielowarstwowych platform wymiany i cyrkulacji [por. Lyster 2016: 127]. Tak pojmowane miasto przestaje być jedynie antropologicznie rozumianym miejscem i zakładnikiem własnej skali geograficznej, co w radykalnej postaci 
pozwala mu się niemal w pełni roztapiać w przestrzeni przepływów. Przykładem takiego funkcjonowania jest irlandzkie Knock, które wymykając się swojemu położeniu i ograniczeniom o charakterze demograficznym (w 2006 r. mieszkało tam 745 osób), stało się jedną z głównych baz linii lotniczych Ryanair, a w efekcie miejską machiną wzrostu dla całej zachodniej Irlandii [Lyster 2016: 22-23].

[T]ym, czego się stąd dowiadujemy jest to, że geografia jest zastępowana jako sprawczyni urbanizacji, ponieważ przestrzeń jest dziś aktywnie generowana przez komunikacyjne przepływy. Inne logistyczne sieci [...] tylko to potwierdzają, co obrazuje: 1. Zwiększenie rozmiaru i znaczenia niektórych obszarów metropolitalnych w stosunku do ich geograficznych początków i niezależnie od ich geograficznej lokalizacji [...]. 2. Telekomunikacyjne przepływy łączące odległe od siebie geograficznie miasta [...]. 3. Łatwość i szybkość, z jaką dystrybuowane są dobra w poprzek terytoriów i geograficznych granic [...] [Lyster 2016: 28-29].

Tak zarysowane procesy potwierdzają epokową zmianę w obszarze polityki infrastruktury, która, będąc do niedawna ważnym, ale służebnym wobec terytorium narodowego i miejskiego czynnikiem integracyjnym [Graham, Marvin 2001: 40-136], coraz mocniej przeobraża się w wehikuł ich dekonstrukcji, tworząc podstawy pod przeskalowanie miast i planetarne upowszechnienie miejskości. To właśnie dzięki temu Easterling [2014: 11-14] może mówić o nowej infrastrukturze ponadpaństwowych połączeń jako fundamentalnych parametrach globalnego urbanizmu, a w konsekwencji systemie operacyjnym, który zarządzając kapitalistycznymi przestrzeniami całego świata, odpowiada równocześnie za kształtowanie codziennego życia nas wszystkich.

\section{TEZA 3: LOGISTYKA RZUCA WYZWANIE MIASTOM GLOBALNYM, TWORZĄC NOWY, HYBRYDALNY TYP MIASTA PRZEMYSLOWO-USŁUGOWEGO}

Rozciagnięcie sieci logistycznych na obszar całej planety nie oznacza, że nie istnieją miejsca, w których zaznaczałyby one swoją obecność mocniej niż w innych. Przykład Chin jest tu najbardziej sugestywny, choć pod różnymi względami konkurują z nimi na przykład Niemcy czy USA. Rola państw narodowych blednie jednak w związku z pojawieniem się nowych miast logistycznych, które dużo wyraźniej integrując się z globalnym łańcuchem dostaw, są też świetną materializacją dla opisywanego wyżej poruszenia/eksplozji formy miejskiej. Wiele z nich - np. Shenzhen, Dubaj, Kalkuta - to wyłaniające się na dawnych kapitalistycznych peryferiach „nowe Wenecje”. Ich rozwój jest możliwy dzięki niższym niż na Zachodzie kosztom pracy, większej dostępności obszarów nie- 
zurbanizowanych, w których lokują się firmy logistyczne oraz środkom finansowym dostępnym w ramach partnerstw prywatno-publicznych. Możliwości te czynią z nich laboratoria zautomatyzowanej produkcji [Rossiter 2012] łączące innowacje $\mathrm{w}$ dziedzinie oprogramowania $\mathrm{i}$ infrastruktury z nowymi technikami nadzorowania i dyscyplinowania pracy.

Bezpośrednie wyłonienie się miast logistycznych zapowiada popularność innych form miejskich powołanych przede wszystkim do mediowania między różnej skali gospodarkami, jak również obsługiwania przepływającego przez nie kapitału handlowego. Są to, po pierwsze, entrepôts, zazwyczaj portowe miasta lokowane na przecięciu głównych arterii handlowych. Ich typowe przykłady to pozaeuropejskie placówki wspierające sieci międzynarodowego handlu, które można traktować jako miejskie produkty merkantylizmu i kolonializmu. Stąd też szereg pełnionych przez nie dodatkowych funkcji - np. administracyjna czy ekstrakcyjna [Sigler 2013: 616-617] - co pozwala o nich myśleć w kategoriach przestrzennych hybryd, dobrze adaptujących się do zmiennych okoliczności politycznych i transformacji kapitalizmu. Potwierdzają to późniejsze kariery takich entrepôts jak Hongkong i Singapur, które rozwijano dla potrzeb usprawnienia wymiany towarowej między Europą a Dalekim Wschodem. Tego rodzaju hybrydalność będzie zresztą charakterystyczna również dla miast logistycznych, dużo bardziej pragmatycznych w swoich wyborach gospodarczych niż typowe miasta poprzemysłowe. Drugi punkt odniesienia to popularyzowane w następstwie procesu dekolonizacji (i osłabienia pozycji entrepôts) gateway cities, traktowane we wczesnej fazie globalizacji jako jej ,punkty transmisyjne” [Sigler 2013: 617]. Zadaniem takich „miejskich bram”, np. Saint Louis czy Winnipeg, było otwieranie regionu na ekonomiczne relacje z gospodarkami narodowymi dzięki skupieniu na określonych sektorach gospodarki (transporcie i usługach handlowych) oraz ekscentrycznej lokalizacji w obrębie regionu. Zachodząca w obu przypadkach peryferyzacja nakłada na tego rodzaju miasta szereg służebnych funkcji względem wymogów koncentrowanego w innych obszarach kapitału. Chodzi tu na przykład o zapewnienie stabilnego funkcjonowania szybko globalizujących się gospodarek narodowych (gateway cities), jak również neutralizowanie cyklicznych kryzysów kapitalizmu (zwłaszcza w kontekście entrepôts i terytoriów niezachodnich), które zachodzi właśnie poprzez stopniowe podporządkowanie niekapitalistycznego zewnętrza [Harvey 2012].

Jeśli zgodzić się z taką genealogią miast logistycznych, trzeba od razu zastrzec, że modus ich funkcjonowania znacznie odbiega od tego, który cechował ich miejskich przodków. Skrajnie odmienna jest zwłaszcza ich pozycja w hierarchii miejskich ośrodków oraz stosunek względem innych miast, co pozwala 
upatrywać w nich jedno z ciekawszych wyzwań dla miast globalnych. Miasta logistyczne to pod pewnymi względami aberracje na gruncie przewidywań, jakie względem procesów miastotwórczych przedstawiali poczytni teoretycy współczesnej gospodarki. Nie wpisują się bowiem ani w obraz powodowanego przez globalizację spłaszczania świata, choć takie są niewątpliwie zapędy sektora logistycznego, ani w geografię miejskich wierzchołków, o których pisali odpowiednio Friedman [2006] i Florida [2008]. To raczej podniesione do skali miejskiej heterotopie, które splatając ze sobą różne logiki ekonomiczne, polityczne i urbanistyczne, materializują wiele spośród najpopularniejszych dyskursów o współczesnym mieście (np. smart city, miasto jako medium, edgecity). Obrazując zarazem stopień integracji globalnej gospodarki i jej heterogeniczność [Tsing 2009], dają też dobry wgląd we wciąż marginalizowane przemiany, które podskórnie modelują nasze myślenie o miejskości, nie przyczyniając się jednak do ustanowienia nowego hegemonicznego modelu miasta wzorem globalnego czy postindustrialnego. Nie są bowiem w ścisłym sensie odpowiednikami tych ostatnich - to raczej sytuowane na ich marginesach autonomiczne sploty infrastruktury przyspieszonej cyrkulacji (,intermodalne terminale transportowe, magazyny, infrastruktura IT, parki kontenerowe i porty" [Rossiter 2012]), które zaszczepiając się na większych jednostkach terytorialnych, pozwalają im na typowy dla asamblażu eksces, wyjście poza własną lokalizację. Inaczej niż stolice miejskiej nowoczesności wolą też działać w ciszy, co pozostaje główną zasadą często niewidocznego i rozproszonego geograficznie sektora logistyki. Wszystko to czyni z nich bardzo nietypowe miasto krawędziowe - nawet jeśli sytuujące się na kresach większych metropolii i dawnego Pierwszego Świata, to stale ważące na przyjmowanych w nich sposobach pracy, konsumpcji i reorganizacji fizycznej tkanki miejskiej.

Nie mając tu miejsca na dokładny opis różnych przykładów miasta logistycznego, zwróćmy tylko uwagę, że etykietę tę odnosi się do bardzo zróżnicowanych przestrzeni łączonych głównie ze względu na ich dystrybucyjną dominantę gospodarczą. Za logistyczne uchodzą z tego powodu miasta-centra komunikacyjne konkretnych korporacji (np. „SuperHub” firmy FedEx w Memphis), miasta portowe organizujące swoją gospodarkę wokół terminali kontenerowych i centrów dystrybucji (Shenzhen, Ningbo-Zhoushan) czy miasta łańcucha dostaw, czyli specjalne strefy logistyczne (w Dubaju, Basrze, Szanghaju), które dzięki swojemu ponad- i pozapaństwowemu statusowi prawnemu oraz przedsiębiorczym modelom zarządzania tkanką miejską stają się jednym z podstawowych protokołów produkcji przestrzeni w ogóle. Poniżej zwrócę się zwłaszcza ku tym ostatnim, pokazując, że prawda o transformacyjnym potencjale logistyki przeja- 
wia się dziś głównie na dawnych peryferiach kapitalistycznego systemu-świata stanowiących kluczowe przestrzenie kontroli i koordynacji globalnego łańcucha dostaw [Rossiter 2016: XVI].

Bardzo wymowny jest tu przypadek Dubaju, traktowanego jako pierwsze i najbardziej innowacyjne miasto logistyczne. W sensie ścisłym chodzi tu tylko o pewną część arabskiej metropolii, a zatem założone w 2007 r. i funkcjonujące jako jedna z autarkicznych prawnie zon Dubai Logistics City (DLC) [Easterling 2014: 25-69]. Jest ona jednak wpisana w wielki plan osadniczy Dubai World Central (wraz z imponującą infrastrukturą cyrkulacji, czyli największym sztucznym portem morskim Jebel Ali i nowym portem lotniczym Al Maktoum International Airport), co wskazuje na kluczową rolę odgrywaną przez logistykę w stale dywersyfikowanej gospodarce ZEA. Jeśli większość miast z rozwiniętą infrastrukturą cyrkulacji nazwać możemy dziś asamblażami, to Dubaj, ze swoim podziałem na różne miasta-strefy (Dubai Knowledge Village, Dubai Industrial City, Dubai Techno Park itd.), stanowi podręcznikowy przykład asamblażu asamblaży. Heterogeniczność każdego z nich ma miejsce na wielu poziomach, choć nigdzie nie jest ona tak rażąca jak w kwestiach organizacji pracy. Zdradza to już typowa dla Dubaju struktura zatrudnienia, która czyni z niego dość paradoksalną postać miasta postindustrialnego. Choć miasta logistyczne opierają się de facto na gospodarce usługowej (handel, transport, telekomunikacja), to jako część globalnej fabryki logistycznej okazują się równocześnie integralną częścią sektora produkcji. DLC stanowi w tej kwestii nietypową dla miast zachodnich hybrydę rozwiązań miasta inteligentnego z rzeczywistością skrajnego wyzysku rodem z pierwszych miast przemysłowych. Bezkolizyjne spotkanie obu gwarantuje bardzo umiejętne wintegrowanie miękkiej infrastruktury [Rossiter 2016: 19], a zatem mediów logistycznych (np. systemów planowania zasobów przedsiębiorstwa (ERP) i identyfikacji radiowej (RFID)) oraz narzędzi biometrycznej kontroli pracowników w twardą infrastrukturę parków kontenerowych, magazynów i centrów dystrybucji. Całe DLC jest podporządkowane władzy kalkulacji, przewidywania i miary, co sprzyja nie tylko zarządzaniu towarami, ale również siłą roboczą. Ta ostatnia poddawana jest nadzorowi zarówno w miejscu pracy (vide indywidualne techniki mierzenia wydajności w czasie rzeczywistym), jak i w rezydencjalnej „wiosce pracowniczej”, określanej czasem jako „luksusowy obóz pracy" [Cowen 2014: 172]. Zdecydowana większość osób zatrudnionych w Dubaju (ok. 85\%) to migranci bez obywatelstwa (z tymczasowym pozwoleniem na pracę), co pozbawia ich podstawowych praw pracowniczych i skazuje na niemal bezwolne wykonywanie zajęć wpisywanych w niechlubny model 3D (dirty, dangerous, demeaning) [Easterling 2014: 54]. Pracownicy nie mają też 
możliwości swobodnego poruszania się po innych obszarach miasta, co uwypukla kluczową dla logistyki sprzeczność między intensyfikowaniem cyrkulacji towarów i ograniczaniem mobilności żywej pracy. DLC zdradza poza tym wiele powinowactw z neoliberalnym modelem miejskiej przedsiębiorczości [Harvey 2012: 144], oferując korzystny pakiet dla inwestorów: zachęty podatkowe (50 lat zwolnienia), brak narzutów kapitałowych czy twardych regulacji pracy.

Co istotne, wyjątkowość Dubaju polega nie tyle na umiejętnym zmieszaniu autorytarnej polityki i neoliberalnego podejścia do handlu [Cowen 2014: 174], a co najwyżej na skali umacniających ten związek inwestycji. Miarą jego sukcesu są bowiem przede wszystkim liczni naśladowcy, którzy produkując podobną infrastrukturę cyrkulacji, obierają ten sam zaostrzony kurs względem pracowników sektora. Sposób funkcjonowania takich przestrzeni, jak Basra Logistics City, logistyczne zony w Shenzhen i Kalkucie czy amerykańskie Oakland Global potwierdzałby zatem promowaną tu tezę o powstaniu nowej hybrydalnej formy miasta przemysłowo-usługowego, które stawiając wyzwanie miastu globalnemu, ma też potencjał, by fundamentalnie zmieniać skromniejsze metropolie i miasta. Potwierdza to popularność dubajskich rozwiązań w wielu europejskich i amerykańskich portach, także w zakresie modelowych rozwiązań w sferze bezpieczeństwa (technologie biometryczne, aparaty nadzoru, dyspozytywy kontrolne dotyczące geografii wejść i korytarzy) [Cowen 2014: 170-177]. „Niezbadane tło dla kapitalistycznych sposobów bycia i wiedzy” [Neilson 2012: 322], za które uznaje się skryty na marginesach systemu sektor logistyczny, wraca w ten sposób do postindustrialnego centrum, podskórnie upowszechniając formy organizacji przestrzeni i modele pracy rodem z peryferyjnego kapitalizmu. To zaś komplikuje obraz proponowany przez Mike'a Davisa [2009], zgodnie z którym główną trzecioświatową innowacją w obszarze kwestii miejskiej jest dziś zastraszająca produkcja przestrzeni nieformalnych (slumsów, bidonvilles itd.). Przypadek miast logistycznych pozwala zwrócić uwagę na inne przykłady peryferyjnej urbanizacji, także te przyczyniające się do globalizacji tzw. „geografią kalkulacji” [Thrift 2004: 182]. To, że skutki obu tych innowacji mogą być tak samo niechętnie przyjmowane przez ich bezpośrednich odbiorców (pracowników portów, mieszkańców miast itd.), jest już dla globalnego kapitału kwestią drugorzędną.

Pozostaje jeszcze kwestia wyzwania konceptualnego. Czy miasto logistyczne może się przyczyniać do innego myślenia o mieście globalnym? Czy jest w stanie dokonać jego prowincjonalizacji? Wstępną odpowiedź na te pytania dają dwa coraz bardziej wpływowe nurty studiów miejskich: postkolonialne badania porównawcze i relacyjna geografia. Pierwszy z nich wskazuje na re- 
dukcjonistyczny i hierarchizujący charakter zachodniej teorii miejskiej, która uprzywilejowując perspektywę miejskich liderów (Nowy Jork, Londyn, Los Angeles itd.), zapomina o kondycji zwyczajnych, często peryferyjnych miast, które poprzez swoje historyczne i współczesne relacje z innymi miejscami, piszą swoje własne opowieści o miejskiej globalizacji i planetarnej urbanizacji. Zarzut ten odnosiłby się tutaj do niepogłębionego spojrzenia na całokształt globalnej gospodarki, która jest nierówno zasilana przez różnego rodzaju sieci, formy cyrkulacji i modele urbanizacji [Robinson 2006: 107-109]. Z kolei zwolennicy geografii relacyjnej oskarżają badania kojarzone z takimi autorami jak Peter Hall czy Saskia Sassen [1991] o niedostateczną wrażliwość na wewnętrzne zróżnicowanie miast globalnych. Zrównanie tych ostatnich z centrami zaawansowanych usług dla kapitału, matecznikami elitarnej siły roboczej i obszarami kontroli dla całej kapitalistycznej gospodarki nie pozwala im dostrzec innych przypadków miejskiej globalności. Dobrym przykładem alternatywnego stanowiska jest koncepcja miast relacyjnych Thomasa Siglera, która, sięgając po przykład Dubaju (oraz Dohy i Panama City), pokazuje, że tego rodzaju ośrodki pełnią z jednej strony zbliżone funkcje do gateway cities, mediując jednak między większymi jednostkami gospodarczymi (systemami globalnymi i regionalnymi), a z drugiej, dzięki swojej hybrydalności i liminalności są w stanie godzić większą liczbę funkcji i platform dla międzynarodowych operacji kapitału niż skupione na usługach finansowych miasta globalne. Miasta relacyjne (w tym logistyczne) byłyby wobec tego innym przypadkiem wiodących ośrodków, które dzięki swoim związkom z ,powstaniem kluczowych sieci infrastrukturalnych w ramach zaawansowanych kapitalistycznych sposobów akumulacji” [Sigler 2013: 619], peryferyjnemu usytuowaniu oraz większej gospodarczej pragmatyczności stanowiłyby nowy, mniej hierarchizujący i bardziej zwyczajny model miejskiego rozwoju. Niosą w ten sposób obietnicę wymknięcia się dyfuzjonizmowi i przestrzennemu elitaryzmowi, które wciąż towarzyszą dominującym spojrzeniom na globalizację, planetarną urbanizację i transformację postindustrialną [Lees, Shin, López-Morales 2016: 4].

\section{PODSUMOWANIE}

Logistyka dość niepostrzeżenie wyrosła w ostatnich latach na jednąz najważniejszych składowych kapitalistycznej gospodarki. Świadczą o tym nie tylko wielomiliardowe obroty całej branży, liczba znaczących inwestycji czy rozpoznawalność stojących za nią marek (Amazon, Wal-Mart, DHL), ale również skala innowacji, na której opiera się całościowo rozumiany kapitalizm (zwłaszcza w dziedzinie 
automatyzacji pracy, ale i na gruncie bezpieczeństwa czy zarządzania informacja). Tacy autorzy jak Anna Tsing [2009] czy Jasper Bernes widzą w tym wręcz asumpt do analizy nowej mutacji kapitalizmu, który coraz mocniej orientuje się na kwestiach cyrkulacji i przepływów kosztem dominującej wcześniej produkcji [Bernes 2013]. Wpływ logistyki dostrzega się dziś na bardzo różnych obszarach, nie wyłączając sztuki [Parker 2013], szkolnictwa wyższego [Rossiter 2016] czy nawet samej kondycji ludzkiej [Tsing 2009], co pokazuje, że kojarzona z nią rewolucja nie ogranicza się z całą pewnością do pola gospodarki.

Głównym celem tego artykułu było wyartykułowanie przekonania, że logistyka stanowi równie ważny impuls transformacyjny, gdy idzie o najnowsze procesy miastotwórcze. Choć od jakiegoś czasu podkreślają to różni badacze [Hesse 2008; Cowen 2014; Rossiter 2016; Lyster 2016; LeCavalier 2016], namysł nad konsekwencjami logistyfikacji dla tkanki miejskiej pozostaje wciąż stosunkowo nieśmiały. Dokonujące się za jej sprawą miejskie restrukturyzacje przebiegają bowiem zwykle w tle innych procesów ekonomicznych, projektów kulturalnych czy działań politycznych, które wpisując się w dominujące, aglomeracyjne rozumienie urbanizacji, najmocniej rozpalają wyobraźnię zarówno badaczy, jak i użytkowników miast. Dostrzegając w infrastrukturze logistycznej jeden z podstawowych wzorców dla produkowanej na całym świecie kapitalistycznej przestrzeni i ważny katalizator dla nowej, asamblażowej ontologii tego, co miejskie, starałem się wydobyć najważniejsze konsekwencje tej podskórnej rewolucji dla przyjmowanych w badaniach miejskich założeń na temat miasta, urbanizacji i miejskości. Stojąc zresztą na stanowisku, że pozostawiając sektor logistyczny w bardzo mu sprzyjającej ciszy, pozbawiamy się szansy na krytyczne zaangażowanie w proces ekonomicznych transformacji, które ważą na życiu zdecydowanej większości z nas.

Takie postawienie sprawy nie wyczerpuje namysłu nad miastotwórczym potencjałem logistyki, cel tego artykułu był oczywiście dużo skromniejszy. Można go wiązać z wciąż nieskończonym i podejmowanym przez szersze środowisko badawcze procesem rozciagania Lefebvre'owskich postulatów dla badań miejskich na kwestię dociekań nad materialnymi podwalinami planetarnej urbanizacji. Jeśli prezentowany artykuł dokłada do tego swoją cegiełkę, podkreślając wage „infrastrukturalnej krytyki zmiany miejskiej” [Vormann 2015: 356, 363], można go uznać, choćby częściowo, za zrealizowany. 


\section{BIBLIOGRAFIA}

Allen A. Bruce. 1997. "The logistics revolution and transportation". Annals of the American Academy of Political and Social Science 553: 106-116.

Amin Ash, Nigel Thrift. 2016. Seeing like a city. Cambridge, UK-Malden, MA: Polity.

Angelo Hillary, David Wachsmuth. 2015. "Urbanizing urban political ecology: A critique of methodological cityism". International Journal of Urban and Regional Research 39(1): $1-14$.

Bernes Jasper. 2013. „Logistics, counterlogistics and the communist prospect”. Endnotes 3: 172-201.

Brenner Neil, Christian Schmid. 2015. “Towards a new epistemology of the urban?”. City 19(2-3): 151-182.

Castells Manuel. 1982. Kwestia miejska. Warszawa: PWN.

Castells Manuel. 2007. Społeczeństwo sieci. Warszawa: WN PWN.

Cowen Deborah. 2014. The deadly life of logistics: Mapping violence in global trade. Minneapolis-London: University of Minnesota Press.

Davis Mike. 2009. Planeta slumsów. Warszawa: KiP.

DeLanda Manuel. 2006. A new philosophy of society: Assemblage theory and social complexity. London-New York: Continuum.

Deleuze Gilles, Felix Guattari. 2016. Anty-Edyp: Kapitalizm i schizofrenia, t. 1. Warszawa: Wyd. KP.

Easterling Keller. 2014. Extrastatecraft: The power of infrastructure space. London-New York. Verso.

Friedman Thomas L. 2006. Świat jest płaski: Krótka historia XXI wieku. Poznań: Rebis.

Gandy Matthew. 2014a. The fabric of space: Water, modernity and the urban imagination. Cambridge, MA: The MIT Press.

Gandy Matthew. 2014b. Where does the city end? W: Implosions/explosions: Towards a study of planetary urbanization. N. Brenner (ed.), 86-89. Berlin: Jovis Verlag GmbH.

Graham Stephen, Simon Marvin. 2001. Splintering urbanism: Networked infrastructures, technological mobilities and the urban condition. London-New York: Routledge.

Harvey David. 2006. Paris, capital of modernity. London-New York: Routledge.

Harvey David. 2012. Bunt miast: Prawo do miasta i miejska rewolucja. Warszawa: Bęc Zmiana.

Harvey David. 2015. Seventeen contradictions and the end of capitalism. London: Profile Books.

Hesse Markus. 2008. The city as a terminal: The urban context of logistics and freight transport. Aldershot: Ashgate.

Hesse Markus. 2010. "Cities, material flows and the geography of spatial interaction: Urban places in the system of chains". Global Networks 10(1): 75-91.

Juskowiak Piotr. 2015. Przestrzenie wspólnoty: Filozofia wspólnotowości w perspektywie badań nad miastem postindustrialnym. Poznań: WN WNS UAM.

Juskowiak Piotr. 2017. „O twórczej destrukcji przestrzeni: Marks i sieci logistyczne”. Praktyka Teoretyczna 4: 250-289.

Kubicki Pawel. 2016. Wynajdywanie miejskości: Polska kwestia miejska z perspektywy długiego trwania. Kraków: NOMOS.

LeCavalier Jesse. 2016. The rule of logistics: Walmart and the architecture of fulfillment. Minneapolis-London: University of Minnesota Press. 
Leder Andrzej. 2014. Prześniona rewolucja: Ćwiczenia z logiki historycznej. Warszawa: Wydawnictwo Krytyki Politycznej.

Lees Loretta, Hyun Bang Shin, Ernesto López-Morales. 2016. Planetary gentrification. Cambridge-Malden, MA: Polity.

Lefebvre Henri. 2003. The urban revolution. Minneapolis-London: University of Minnesota Press.

Levinson Marc. 2016. The box: How the shipping container made the world smaller and the world economy bigger. Princeton-Oxford: Princeton University Press.

Lyster Claire. 2016. Learning from logistics: How network change our cities. Basel: Birkhauser Verlag GmbH.

Majer Andrzej. 2014. Odrodzenie miast. Warszawa-Łódź: WN SCHOLAR - Wydawnictwo Uniwersytetu Łódzkiego.

Marks Karol. 1977. Kapitat. Tom 2. Proces cyrkulacji kapitatu. Warszawa: KiW.

Marks Karol. 1986. Zarys krytyki ekonomii politycznej. Warszawa: KiW.

McFarlane Colin. 2011. "The city as assemblage: Dwelling and urban space". Environment and Planning D 29: 649-671.

Merrifield Andy. 2016. Nowa kwestia miejska. Warszawa: WN PWN.

Mezzadra Sandro, Brett Neilson. 2013. Border as method, or the multiplication of labor. Durham-London: Duke University Press.

Neilson Brett. 2012. "Five theses on understanding logistics as power". Distinktion 13(3): 322-339.

Neilson Brett, Ned Rossiter. 2011. Still waiting, still moving: On labour, logistics and maritime industries. W: Stillness in a mobile world, D. Bissell, G. Fuller (eds.), 51-68. London-New York: Routledge.

Parker Martin. 2013. "Containerisation: Moving things and boxing ideas". Mobilities 8(3): 368-387.

Robinson Jennifer. 2006. Ordinary cities: Between modernity and development. London-New York: Routledge.

Rossiter Ned. 2012. The logistical city: Software, infrastructure, labor. http://nedrossiter. org/?p=324 [dostęp: 30.10.17].

Rossiter Ned. 2016. Software, infrastructure, labor: A media theory of logistical nightmares. London-New York: Routledge.

Sassen Saskia. 1991. The global city: New York, London, Tokyo. Princeton-Oxford: Princeton University Press.

Sigler Thomas J. 2013. "Relational cities: Doha, Panama City, and Dubai as 21 st century entrepots". Urban Geography 34(5): 612-633.

Soja Edward W., J. Miguel Kanai. 2014. The urbanization of the world. W: Implosions/explosions: Towards a study of planetary urbanization. N. Brenner (ed.), 142-159. Berlin: Jovis Verlag GmbH.

Thrift Nigel. 2004. "Remembering the technological unconscious by foregrounding knowledges of position". Environment and planning D: Society and Space 22: 175-190.

Tsing Anna. 2009. "Supply chains and the human condition". Rethinking Marxism 21(2): $148-176$.

Urry John. 2007. Mobilities. London: Polity.

Urry John. 2013. Offshoring. Warszawa: WN PWN.

Vormann Boris. 2015. "Toward an infrastructural critique of urban change: Obsolescence and changing perceptions of New York City“s waterfront". City 19(2-3): 356-364. 
Piotr Juskowiak

\title{
THE SUBCATENOUS REVOLUTION: THREE THESES ON THE URBAN-FORMING POTENTIAL OF LOGISTICS
}

\begin{abstract}
The article is a polemical attempt to rethink the role of the logistics sector in the most important transformations of the contemporary urban fabric. Despite many indications proving its influence as a crucially important condition for the emergence of a post-industrial city as well as a catalyst for further, equally significant transformations, the revolution in logistics remains one of the most marginalized events in the field of critical urban studies. One of the reasons for such neglect is based in the dominant perspective on urbanization which, focusing mainly on the issue of agglomeration and Western-based urban phenomena, tends to ignore other, more peripheral urbanization processes. These include the global spread of circulation infrastructure, which is an indispensable condition for the materialization of a Lefebvrian urban society. Contrary to that perspective, logistical networks will be treated here as one of the most important patterns of the production of space, contributing to the proliferation of the urban in non-urbanized areas and providing justifications for new, assemblage-oriented ontologies of the city.
\end{abstract}

Keywords: logistics, logistical city, extended urbanization, infrastructure, circulation, the urban, assemblage 